\title{
Assimilation of Ammonia During Sporogenesis of Saccharomyces cerevisiae: Effect of Ammonia and Glutamine
}

\author{
By COLETTE DELAVIER-KLUTCHKO, \\ ODILE DURIEU-TRAUTMANN, PIERRE ALLEMAND AND \\ JEAN TAVLITZKI \\ Unité de Génétique Cellulaire, Institut de Recherche en Biologie Moleculaire, \\ C.N.R.S., Universite Paris VII, 2 Place Jussieu, 75221 Paris Cedex 05, France
}

(Received 30 April 1979)

\begin{abstract}
Comparison of the pools of glutamic acid and glutamine and of the specific activities of glutamine synthetase and glutamate dehydrogenases in sporulating $a / \alpha$ and non-sporulating $\alpha / \alpha$ cells of Saccharomyces cerevisiae revealed a difference in their nitrogen metabolism. Glutamine synthetase and glutamine appeared to be necessary for the sporulation process, glutamine playing, at least, a catabolic role. However, exogenous glutamine as well as ammonia inhibited sporulation while glutamic acid did not. Glutamine seemed to act through its amino group. Both inhibitors had at least two sites of action, one effective early in sporulation and related to DNA synthesis and the other acting later and not related to it.
\end{abstract}

\section{INTRODUCTION}

Starvation of the yeast Saccharomyces cerevisiae induces a differentiation process leading to meiosis and sporulation of diploid $(a / \alpha)$ cells. This process is inhibited by ammonia and some other nitrogen compounds (Miller, 1963; Piñon, 1977) but very little is known about the metabolism of ammonia in sporulating cells. In this paper, we report our studies on the activities of enzymes involved in ammonia assimilation (glutamine synthetase, NAD- and NADP-linked glutamate dehydrogenases), the effect of the substrates of these enzymes on the sporulation process, and the variation in the sizes of pools of free glutamine and glutamic acid during the first hours after the transfer of cells to the sporulation medium with or without ammonia.

\section{METHODS}

Yeast strains, growth and sporulation. Diploid cells of Sacharomyces cerevisiae 532 a/ $\alpha$ and $533 \alpha / \alpha$, isogenic except for their mating type (Pellucuer, 1973), were used. The $a / \alpha$ cells were grown and allowed to sporulate as described by Durieu-Trautmann \& Delavier-Klutchko (1977). The $\alpha / \alpha$ cells, which are unable to sporulate, were used as a control.

Enzyme activities. Extracts were prepared at $4{ }^{\circ} \mathrm{C}$ by passing suspensions of cells in $100 \mathrm{~mm}$-potassium phosphate buffer pH 7.8, containing $1 \mathrm{~mm}-2$-mercaptoethanol, through a French press at $100 \mathrm{MPa}$. Cell debris was removed by centrifuging for $30 \mathrm{~min}$ at $30000 \mathrm{~g}$ and the supernatant was dialysed overnight at $4{ }^{\circ} \mathrm{C}$ against buffer similar to that used for extraction.

Activities of NAD-linked glutamate dehydrogenase (NAD-Gdh; EC 1.4.1.2) and of NADP-linked glutamate dehydrogenase (NADP-Gdh; EC 1.4.1.4) were estimated by determining the rate of NADH or NADPH oxidation at $25{ }^{\circ} \mathrm{C}$ (Boehringer, 1968). The rate of reaction with NAD-Gdh was corrected by subtracting the rate of NADH oxidation observed in the absence of 2-oxoglutarate.

The activity of glutamine synthetase (GS; EC 6.3.1.2) was measured by assaying transferase activity (Woolfolk et al., 1966).

Protein was determined by the Folin method of Lowry, using bovine serum albumin as standard.

Glutamate and glutamine pools. Samples containing about $10^{8}$ cells were collected on membrane filters 


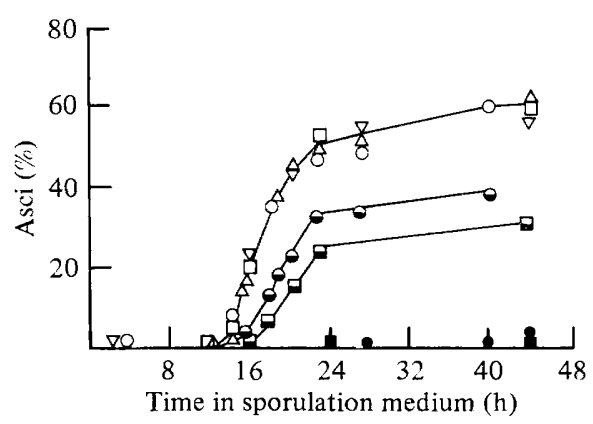

Fig. 1. Effect of ammonia and glutamine on sporulation. $a / \alpha$ cells were incubated in sporulation medium with the following additions: none $(\triangle) ; 1 \mathrm{~mm}$-ammonia $(\square) ; 2.5 \mathrm{~mm}$-ammonia $(\square)$; $5 \mathrm{~mm}$-ammonia $\pm 40 \mathrm{~mm}$-glutamic acid $(\square) ; 2.5 \mathrm{~mm}$-glutamine $(\bigcirc) ; 5$ mM-glutamine $(\odot) ; 7.5 \mathrm{~mm}-$ glutamine $(\Theta) ; 40 \mathrm{~mm}$-glutamic acid $(\nabla)$. Sporulation was measured by counting the number of asci formed. The viability of cells exposed to the inhibitors was only slightly reduced and was still $60 \%$ after $24 \mathrm{~h}$.

(Millipore) and washed rapidly three times with $10 \mathrm{ml}$ portions of ice-cold water. The filters were extracted by heating for $5 \mathrm{~min}$ with $5 \mathrm{ml}$ water in a boiling water bath, the extracts were filtered and taken to dryness at $25^{\circ} \mathrm{C}$, and the residues were dissolved in water for electrophoretic analysis. Electrophoresis was performed at pH 6.5 on Whatman $3 \mathrm{MM}$ paper for $30 \mathrm{~min}$ at $80 \mathrm{~V} \mathrm{~cm}^{-1}$. Amino acids wererecovered by elution with $6 \mathrm{M}-\mathrm{HCl}$ and eluates were hydrolysed at $110^{\circ} \mathrm{C}$ overnight and analysed using a Technicon TMS amino acid analyser (Spackman et al., 1958).

\section{RESULTS AND DISCUSSION}

Addition of either ammonia or glutamine at the time when cells were transferred to sporulation medium inhibited sporulation and no growth was observed under the conditions used (Fig. 1): 5 mM-ammonium sulphate or $7.5 \mathrm{~mm}$-glutamine completely suppressed ascus formation; at lower concentrations, there was a lag in the appearance of the first asci and a reduction in the final sporulation yield. In contrast, glutamic acid did not inhibit sporulation and did not relieve the glutamine- or ammonia-mediated inhibition even at concentrations as high as $40 \mathrm{~mm}$ (Fig. 1) (entry of glutamic acid into the cells was verified by using $\left[{ }^{14} \mathrm{C}\right]-$ glutamic acid). As expected, cells homozygous for mating type $(\alpha / \alpha)$ neither sporulated nor grew under sporulation conditions.

Subsequent experiments were designed to determine if ammonia and glutamine exert their inhibitory action at a specific step (or steps) in the sporulation process, and if the inhibitory effect was reversible. As shown in Table 1, ammonia and glutamine blocked sporulation when added within $12 \mathrm{~h}$ of transfer to sporulation medium, but if the addition was made after $12 \mathrm{~h}$, some asci were formed, and the later the addition the greater the number of asci observed. Inhibition was reversible up to about $12 \mathrm{~h}$. If the inhibitor was removed after $12 \mathrm{~h}$, some inhibition was observed, its extent being dependent on the time of removal of the inhibitor. Thus, $12 \mathrm{~h}$ appeared to be the point of commitment to spore formation for strain $532 a / \alpha$ under the conditions used. These results agree with those of previous experiments (Durieu-Trautmann \& Delavier-Klutchko, 1977; Delavier-Klutchko \& DurieuTrautmann, 1978) which showed that, in sporulating $(a / \alpha)$ as well in non-sporulating $(\alpha / \alpha)$ cells, glutamine and ammonia prevent RNA, protein and glycogen synthesis from occurring in the sporulation medium after $4 \mathrm{~h}$. RNA, protein and glycogen synthesis occurring within $4 \mathrm{~h}$ is insensitive to these inhibitors. This inhibitory effect is reversible. In addition, glutamine and ammonia reduce and slow down DNA synthesis (a specific event of sporogenesis), which starts at around $4 \mathrm{~h}$ (Durieu-Trautmann \& Delavier-Klutchko, 1977; Piñon, 1977). Thus, these inhibitors have at least two sites of action, one at around $4 \mathrm{~h}$ and another at 
Table 1. Effect of glutamine and ammonia on sporulation when added or removed at different times

The percentage of asci formed, relative to a control without inhibitor, was determined $40 \mathrm{~h}$ after transferring the cells to sporulation medium (the control contained $55 \%$ asci at this time). The inhibitor ( $5 \mathrm{~mm}$-ammonium sulphate or $10 \mathrm{~mm}$-glutamine) was either added to the sporulation medium at the time indicated and left in the medium or added at $0 \mathrm{~h}$ and removed at the time indicated by transferring cells to fresh sporulation medium. Similar results were obtained with both inhibitors.

Time of addition or removal of inhibitor

0
4
11
12
$3-14$
$5-16$
$7-19$

0

4

11

12

13-14

$17-19$

20

$\begin{array}{cc}\begin{array}{c}\text { Addition of } \\ \text { inhibitor }\end{array} & \begin{array}{c}\text { Removal of } \\ \text { inhibitor }\end{array} \\ 0 & 100 \\ 0 & 100 \\ 0 & 90 \\ 2 & 73 \\ 22 & 66 \\ 26 & 59 \\ 57 & 2 \\ 90 & 0\end{array}$

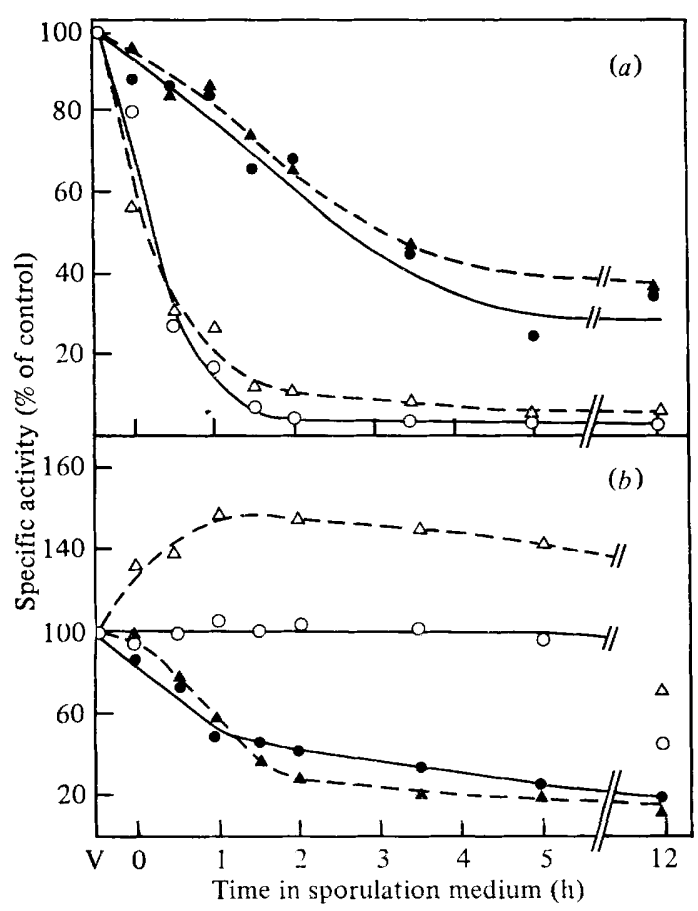

Fig. 2. NAD-linked $(a)$ and NADP-linked $(b)$ glutamate dehydrogenase activities of diploid $a / \alpha$ and $\alpha / \alpha$ cells during incubation in sporulation medium with or without ammonia: $a / \alpha$ cells in sporulation medium $(O) ; \alpha / \alpha$ cells in sporulation medium $(\triangle) ; a / \alpha$ cells in sporulation medium $+5 \mathrm{~mm}$-ammonia $(\circlearrowleft) ; \alpha / \alpha$ cells in sporulation medium $+5 \mathrm{~mm}$-ammonia $(\Delta)$. Initial specific activities [ $\mu$ mol NADH or NADPH oxidized $\left.h^{-1}(\mathrm{mg} \text { protein })^{-1}\right]:$ NAD-Gdh in $a / \alpha$ cells, $9 \cdot 8$, and in $\alpha / \alpha$ cells, 15.5; NADPH-Gdh in $a / \alpha$ cells, $4 \cdot 8$, and in $\alpha / \alpha$ cells, 5.3. V indicates cells in the vegetative state. 


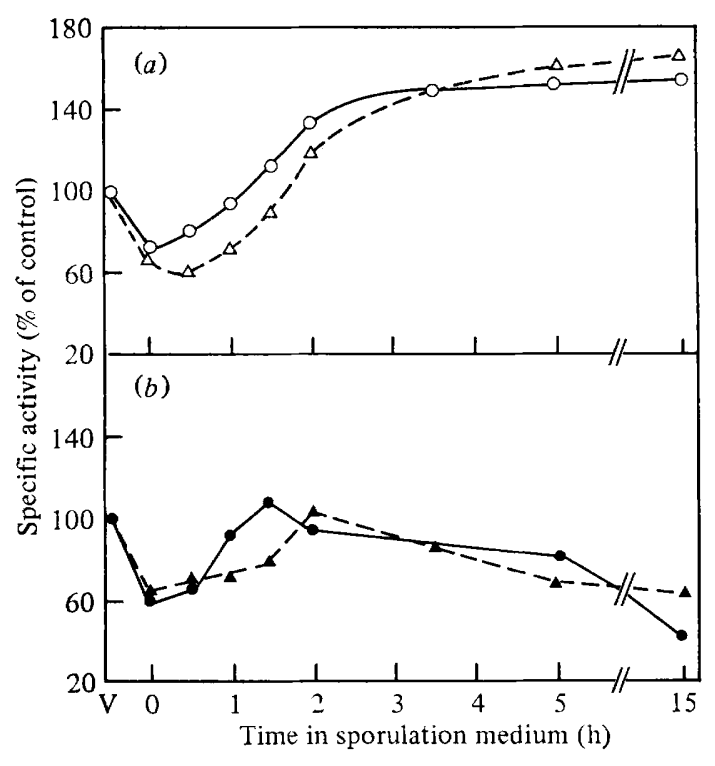

Fig. 3. Glutamine synthetase activities of diploid $a / \alpha$ and $\alpha / \alpha$ cells during incubation in sporulation medium $(a)$ and in sporulation medium +5 mm-ammonia $(b)$. Symbols as in Fig. 2. Initial specific activities [ $\mu$ mol $\gamma$-glutamyl hydroxamate formed $\mathrm{h}^{-1}(\mathrm{mg} \text { protein })^{-1}$ ]: in $a / \alpha$ cells, 126 , and in $\alpha / \alpha$ cells, 114 .

approximately $12 \mathrm{~h}$, when DNA synthesis is completed. Piñon (1977) observed an inhibitory effect of ammonia and glutamine on sporulation and DNA synthesis of $S$. cerevisiae, but he reported that this effect was irreversible and that glutamate was able to prevent it to some extent, observations that do not agree with ours.

The activities of NAD-Gdh, NADP-Gdh and GS under sporulation conditions were measured in extracts of $a / \alpha$ and $\alpha / \alpha$ cells in order to distinguish specific sporulation events. A very rapid loss of activity of NAD-Gdh occurred in both $a / \alpha$ and $\alpha / \alpha$ cells in the absence of ammonia (Fig. $2 a$ ). In the presence of ammonia, the enzyme activities of $a / \alpha$ and $\alpha / \alpha$ cells were lost at a much slower rate and to a lesser extent. The rapid decrease of NAD-Gdh activity was due to proteolytic degradation, as suggested by Betz \& Weiser (1976) and as shown in our laboratory (unpublished results), and ammonia at least partly prevented this degradation. The pattern of change in NADP-Gdh in the absence of ammonia was different in strains $a / \alpha$ and $\alpha / \alpha$ (Fig. $2 b$ ): in sporulating cells, its activity was unaffected for at least $5 \mathrm{~h}$, whereas in cells unable to sporulate, its activity increased by $50 \%$ within the first hour and then remained constant. Addition of ammonia to the sporulation medium promoted a rapid decrease in the activity of NADP-Gdh in both cell types (Fig. $2 b$ ). The patterns of variation of activity of GS in $a / \alpha$ and $\alpha / \alpha$ cells transferred to a nitrogen-free medium were identical (Fig. $3 a$ ): the enzyme activities fell after the shift and then increased reaching 130 to $160 \%$ of their original values after $5 \mathrm{~h}$. When the sporulation medium contained ammonia or glutamine (Fig. 3b), a similar decrease in the GS activities of both $a / \alpha$ and $\alpha / \alpha$ cells was observed at $0 \mathrm{~h}$, as described above, followed by a slow rise; activities reached the initial level within $2 \mathrm{~h}$ and then declined slowly. The initial loss of activity might be due either to a rapid proteolytic degradation of GS, or to the conversion of the active form to a less active one, as in Candida utilis (Sims et al., 1974) and in Neurospora crassa (Kapoor et al., 1969).

In parallel with the assays of enzyme activities, the changes in the sizes of the pools of free glutamic acid and glutamine were followed in cells transferred to sporulation medium (Table 2). In both $a / \alpha$ and $\alpha / \alpha$ cells, the glutamine concentration decreased rapidly and 
Table 2. Changes in glutamic acid and glutamine contents of cells exposed to sporulation medium with or without ammonia

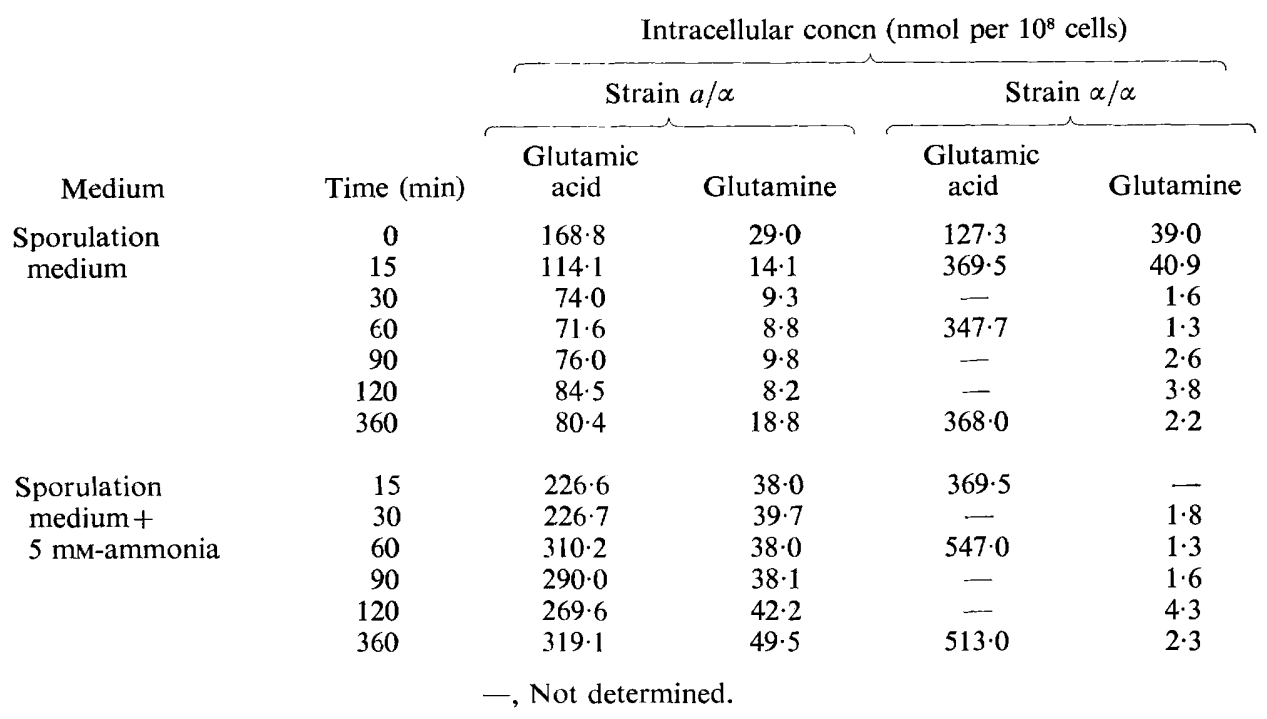

remained low, while, as noted above, the activity of GS increased. This suggests that GS and/or glutamine or some product of its metabolism, are necessary, though not specific, for sporulation. This hypothesis is confirmed by the recent findings of E. Dubois \& J. M. Wiame (personal communication) who observed that a glutamine synthetase-less strain of $S$. cerevisiae was unable to sporulate. The glutamic acid pool differed in $a / \alpha$ and $\alpha / \alpha$ cells. In $a / \alpha$ cells, the concentration of free glutamic acid declined (the activity of the anabolic glutamate dehydrogenase was constant), whereas in $\alpha / \alpha$ cells, it increased and reached a value almost five times higher than that in $a / \alpha$ cells. At the same time NADP-Gdh activity also increased. This result shows a disparity in the glutamate metabolism of the two strains which could relate to the sporulation process, but we do not yet know how glutamate acts. When ammonia was added to the sporulation medium, a difference in the nitrogen metabolism of the two strains was also observed: the glutamine pool decreased in $\alpha / \alpha$ cells (as in the absence of inhibitor) but it increased slightly in $a / \alpha$ cells; the glutamic acid pool behaved in a similar way in both types of cells but was larger in $\alpha / \alpha$ than in $a / \alpha$ cells.

The observation that glutamic acid did not inhibit sporulation whereas glutamine and ammonia did was not expected since glutamic acid is the first compound of ammonia assimilation in growing cells of S. cerevisiae (Jones et al., 1969; Witt \& Holzer, 1964) and is, through GS, a precursor of glutamine. Moreover, in the presence of ammonia, both the glutamine and glutamic acid pools were increased. One explanation could be that the glutamine formed endogenously is accumulated in the vacuoles (Wiemken \& Dürr, 1974) and is not available as an inhibitor. Another hypothesis is that glutamine, rather than glutamic acid, is the first product of ammonia assimilation and GS is the first enzyme involved in this process, rather than NADP-Gdh. This would suggest the involvement of an enzyme such as glutamate synthase. This enzyme operates in bacteria (Elmerich \& Aubert, 1971; Tempest et al., 1973). Although the existence of glutamate synthase is controversial in $S$. cerevisiae (Brown et al., 1973), Roon et al. (1974) have reported evidence for it in cells growing on nonlimiting concentrations of ammonia. Further studies using mutants in ammonia metabolism would help to resolve these problems. 
This study was supported by the Centre National de la Recherche Scientifique, the Délégation Générale à la Recherche Scientifique et Technique (Convention no. 67 0075) and by the Commisariat à l'Energie Atomique. We thank Dr P. Galzy for the gift of strains and Dr A. Delfour and Dr F. Bon for analyses of amino acids pools.

\section{REFERENCES}

Betz, H. \& Weiser, U. (1976). Protein degradation during yeast sporulation. Enzyme and cytochrome patterns. European Journal of Biochemistry 70, 385-395.

Boehringer, C. F. (1968). Biochemica Catalogue. Mannheim: Boehringer.

Brown, C. M., Burn, V. J. \& Johnson, B. (1973). Presence of glutamate synthetase in fission yeasts and its possible role in ammonia assimilation. Nature, New Biology 246, 115-116.

Delavier-KlutchKo, C. \& Durieu-Trautmann, O. (1978). Effect of ammonia on glycogen metabolism during sporulation of Saccharomyces cerevisiae. Journal of General Microbiology 108, 169-171.

Durieu-Trautmann, O. \& Delavier-Klutchko, C. (1977). Effect of ammonia and glutamine on macromolecule synthesis and breakdown during sporulation of Saccharomyces cerevisiae, Biochemical and Biophysical Research Communications 79, 438-442.

Elmerich, C. \& Aubert, J. P. (1971). Synthesis of glutamate by a glutamic:oxoglutarate amidotransferase (NADP oxidoreductase) in Bacillus megaterium. Biochemical and Biophysical Research Communications 42, 371-376.

Jones, M., Pragnell, M. J. \& Pierce, J. S. (1969). Absorption of amino acids by yeasts from a semideined medium simulating wort. Journal of the Institute of Brewing 75, 520-536.

KAPOOR, M., BRAY, D. F. \& WARD, G. W. (1969). Glutamine synthetase of Neurospora crassa. Inactivation by urea and protection by some substrates and allosteric effectors. Archives of Biochemistry and Biophysics 134, 423-433.

Mrller, J. J. (1963). The metabolism of yeast sporulation. V. Stimulation and inhibition of sporulation and growth by nitrogen compounds. Canadian Journal of Microbiology 9, 259-277.

Pellecuer, M. (1973). Contribution à l'étude du caractère sexuel chez Saccharomyces cerevisicie Hansen. Thèse de Spécialité, U.S.T.L., Montpellier, France.

PIÑON, R. (1977). Effects of ammonium ions on sporulation of Saccharomyces cerevisiae. Experimental Cell Research 105, 367-378.

Roon, R. J., Harvey, L. E. \& Larimore, F. (1974). Glutamate synthetase: properties of reduced nicotinamide adenine dinucleotide dependent enzyme from Saccharomyces cerevisiae. Journal of Bacteriology 118, 89-95.

Sims, A. P., Toone, J. \& Box, V. (1974). The regulation of glutamine synthesis in the food yeast Candida utilis: the purification and subunit structure of glutamine synthetase and aspects of enzyme deactivation. Journal of General Microbiology 80, 485-499.

Spackman, D. H., Stein, W. H. \& Moore, S. (1958). Automatic recording apparatus for use in the chromatography of amino acid. Analytical Chemistry 30, 1190-1206.

Tempest, D. W., Meers, J. M. \& Brown, C. M. (1973). Glutamate synthase (GOGAT): a key enzyme in the assimilation of ammonia by prokaryotic organisms. In The Enzymes of Glutamine Metabolism, p. 167. Edited by S. Prusiner \& E. R. Stadtman. New York: Academic Press.

Wiemken, A. \& DurR, M. (1974). Characterization of amino acid pools in the vacuolar compartment of Saccharomyces cerevisiae. Archives of Microbiology 101, 45-57.

WITT, I. \& Holzer, H. (1964). Bautweg des $\mathrm{NH}_{4}^{+}$ Einbaues in Glucose oxydierender Bäckerhefe. Biochemsche Zeitschrift 339, 255-265.

Woolfolk, C., Shapiro, B. \& Stadtman, E. R. (1966). Regulation of glutamine synthetase. I. Purification and properties of glutamine synthetase of Escherichia coli. Archives of Biochemistry and Biophysics 116, 177-192. 